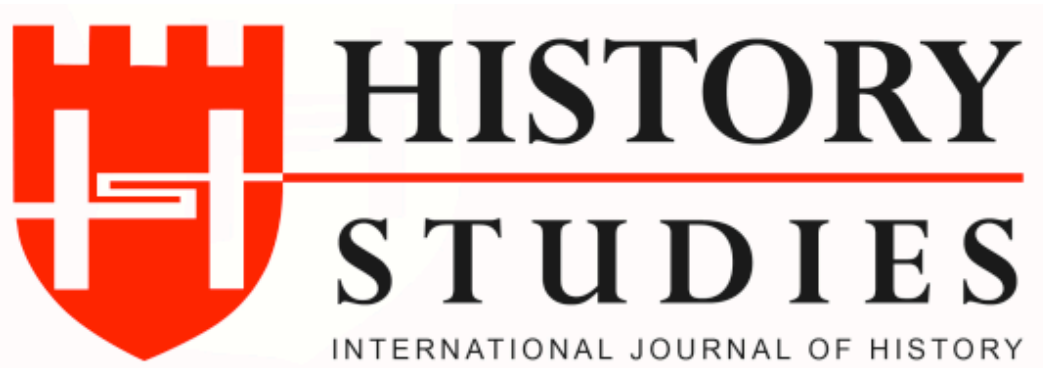

ISSN: 13094173 (Online) 1309 - 4688 (Print)

Volume 9 Issue 3, September 2017, p. 9-19

DOI: $10.9737 /$ hist.2017.538

\title{
Arşiv Belgelerine Göre Atatürk Döneminde Ziraat, Sanayi ve Ticaret Sektörlerindeki Bazı Gelişmeler (1923-1938)
}

According to Archieve Documents, Some Developments in Agriculture, Industry and Trade Sectors During the Period of Atatürk (1923-1938)

\author{
Yrd. Doç. Dr. Mehmet AYDIN \\ (ORCID: 0000-0002-4552-1913) \\ Ondokuz Mayls Üniversitesi - Samsun
}

\begin{abstract}
Öz:Atatürk döneminin önemli konularından biri de devletin iktisadi ve ticari gelişimidir. Nitekim Mustafa Kemal (ATATÜRK)'in İzmit'te 19 Ocak 1923 tarihinde bazı İstanbul gazetecilerine vermiş olduğu beyanatındaki "Yeni Türkiye Devleti cihangir bir devlet olmayacaktır; fakat yeni Türkiye Devleti iktisadi bir devlet olacaktır" şeklindeki sözleri Cumhuriyet döneminde ekonomiye verilen değeri göstermektedir. Bu çerçevede Atatürk döneminde iktisadın hemen her alanında önemli adımlar atılmış her sahada kayda değer gelişmeler olmuştur. Bu çalışmada Atatürk döneminde ticaret ve iktisada verilen önem ve bunun sonucunda ortaya çıkan iktisadi gelişmeler söz konusu dönemde hazırlanmış olan ve Cumhuriyet Arşivleri bünyesinde yer alan bazı raporlar çerçevesinde ortaya konulacaktır.
\end{abstract}

\begin{abstract}
Anahtar Kelimeler: Ticaret,Tarım,.Sanayi, Madencilik,Endüstri
Abstract: One of the important issue of Ataturk era is the financial and commercial development of the state. Hence, the Ataturk's words that is expressed during his declaration to some Istanbul journals in 19th January, 1923 in Izmit "New State of Turkey will not be a World state; but new state of Turkey will be a financial state" reveal the importance that is given to economy in Republic period. Within this framework, considerable steps have been taken in all fields of economy and considerably developments have been arised in all fields. With this study, the importance that was given to commercial and finance in Ataturk period and financial developments and resultant of this importance will be revealed within the scope of some reports that are prepared within Republic Archives at the perion in question.
\end{abstract}

Keywords: Trade, Agriculture, Economy, Mining, İndustry

19 yüzyıl ortalarından itibaren batı kapitalist dünya ile sıkı bir ilişki içerisine girmek mecburiyetinde kalmış olan Osmanlı Devleti bir yandan siyasi yapısını hızla modern devlet hayatının gerekleri çerçevesinde yenilerken; diğer yandan da iktisadi ve ticari hayatta kapitalist ekonomi anlayışının bazı kurum ve kurallarını kabul etmeye ve kısmen uygulamaya başlamıştır. $\mathrm{Bu}$ çerçevede imparatorluğun özellikle liman kentleri ve batı dünyasına yakın coğrafyalarında iktisadi ve ticari hayat eskiye göre hızla değişim sürecine girmiştir. Bununla birlikte bütün modernleştirme çabalarına rağmen gerek klasik dönemin tarım toplum yapısının etkisini uzunca süre devam ettirmesi gerekse imparatorluğun özellikle Rusya ile giriştĭgi savaşlar ve bu savaşların ağır ekonomik ve demografik etkileri beklenen düzeyde bir iktisadi ve ticari hayatın oluşumunu mümkün kılmamıştır. İmparatorluğun kurucu unsuru Müslüman nüfus iktisaden klasik dönemdeki statüsünü muhafaza ederken, gayrımüslim unsurlar özellikle de Rum ve Ermeni tüccarlar kapitalist ilişkinin nimetlerinden fazlaca yararlandılar ve iktisadi hayatta belirleyici güç oldular. 
II. Meşrutiyetin ilanından sonra Türkiye'deki siyasetin belirleyici ve etkin gücü haline gelen İttihat ve Terakki Fırkası 1913 yılından itibaren kurduğu tek parti yönetimiyle özellikle I.Dünya savaşı yıllarında ülkenin iktisadi hayatındaki dengeleri değiştirmek amacıyla izlediği milli iktisat politikalarıyla Müslüman bir tüccar sınıfı oluşturmaya çalışmıştır. ${ }^{1}$ Bütün bu çabalara rağmen milli iktisat politikaları savaş yıllarının da etkisiyle ülkenin iktisadi yaşamında son derece sınırlı bir etki yaratmış özellikle sanayi alanında alınan tedbirlere rağmen istenilen düzeyde bir gelişme olamamıştır. Savaşın ardından başlayan Milli Mücadele ise iktisadi ve ticari hayatın oldukça olumsuz etkilenmesine neden olmuştur. Milli Mücadele başarıyla tamamlandıktan ve Lozan barış süreci başladıktan sonra yeni Türkiye Devleti'nin kuruluş sürecinde iktisadi durum ve alınması gereken tedbirler yeni siyasi kadrosunun en önem verdiği konu haline gelmiştir. Nitekim Mustafa Kemal (Atatürk) 19 Ocak 1923 tarihinde İstanbul gazetecilerine verdiği beyanatında "Yeni Türkiye Devleti cihangir bir devlet olmayacaktır; fakat yeni Türkiye Devleti iktisadi bir devlet olacaktır"2 sözleriyle bu önemi açıkça ortaya koymuştur. Bu çerçevede Lozan Barış görüşmelerinin ara döneminde Şubat 1923 'te gerçekleştirilen İzmir İktisat Kongresinde Türkiye'deki iktisadi durum ve bundan sonra takip edilecek ekonomi politikaları etraflıca ele alınmış ve karar haline getirilmiştir.

$\mathrm{Bu}$ çalışmada, İzmir İktisat Kongresinde belirlenen ve Cumhuriyet'in ilanından sonra hızla uygulamaya konulan ekonomi politikalarının ve uygulamalarının ülkenin iktisadi ve ticari gelişiminde ne kadar etkili olduğu başta sanayi olmak üzere tarım, ticaret ve madencilik gibi başlıca iktisadi alanlarda gelinen nokta Atatürk döneminde değişik tarihlerde hazırlanmış bazı raporlar dikkate alınarak ortaya konulmaya çalışılacaktır

Söz konusu raporlarda dikkati çeken bir husus hemen hepsinde Cumhuriyet dönemindeki iktisadi ve ticari gelişmeler hakkında bilgi verilmezden evvel kısaca Osmanlı imparatorluğundaki durum ile ilgili olarak daha çok olumsuzlaştırma temelli yapılmış olan değerlendirmelerdir. 1938 yılına ait bir raporda, Osmanlı imparatorluğunun iktisadi ve ticari durumu ile ilgili yapılan değerlendirmede imparatorluğun özellikle yükseliş döneminde başta hububat, sebze ve meyve ziraatı olmak üzere, mensucat ve çeşitli el sanatları ve bir çok iktisadi faaliyet açısından diğer devletlerden ileri bir durumda olduğu ticari açıdan da Önasya ve Akdeniz'de etkili bir rol oynadığına dikkat çekilmekle birlikte, daha sonraları bazı milletlere tanınan imtiyazlar başta olmak üzere izlenen yanlış politikalar nedeniyle her açıdan zengin olan ülkenin yabancı devletlerin etkisi altında bir hammadde kaynağı ve halkın da "aciz bir rençper" seviyesine düşürüldüğü ve giderek ekmeği bile ithal etmek mecburiyetinde kalan bir ülke konumuna getirildiğine dikkat çekilmiştir. Eski dönemin yergisi mahiyetinde olan bu değerlendirme yeni dönemi övme ve önceleme eğilimlerinin hemen her alanda yapıldığı gibi iktisadi alandaki değerlendirmelere de bir örnek teşkil etmesi bakımından oldukça dikkat çekmektedir. ${ }^{3}$ Zira söz konusu raporda Osmanlı imparatorluğunun son dönemindeki olumsuz iktisadi durumuna dikkat çekildikten sonra "Genç Cumhuriyetimiz asırların bozduğunu seneler içinde tekrar yapmış ve yapmaktadır. Siyasi iktidarı da iktisadi aczi nispetinde olan bir memleketten bugünkü Türkiye işte şu 15 sene içinde yaratıldı" cümleleriyle Cumhuriyet dönemi iktisadi gelişime büyük bir övgü yapıldığı görülmektedir. ${ }^{4}$ Bununla birlikte söz konusu raporlar Cumhuriyet dönemindeki iktisadi ve ticari gelişim hakkında oldukça detaylı

\footnotetext{
*Yrd.Doç.Dr., Ondokuz Mayıs Üniversitesi, Eğitim Fakültesi Öğretim Üyesi.

${ }^{1}$ I. Dünya Savaşı yıllarında uygulanan Milli İktisat politikaları hakkında bkz. Zafer Toprak, Milli İktisat-Milli Burjuvazi, Tarih Vakfi Yurt Yayınları, İstanbul, 1995.; Zafer Toprak, Türkiye'de Ekonomi ve Toplum (1908-1950) Ittihat Terakki ve Devletçilik, Tarih Vakfi Yurt Yayınları, İstanbul,1995.

${ }^{2}$ BCA, 490.01/ 1455.38.2, s.3.

${ }^{3}$ BCA, 490.01/ 1455.38.2, s.1.

${ }^{4}$ BCA, 490.01/ 1455.38.2, s.2.
} 
bilgiler içermektedir. Aşağıda alt başlıklar altında ele alınacak konular tamamen bu raporlarda yer alan bilgilere dayandırılmıştır.

\section{Ziraat}

Milli Mücadeleyle son bulan ve on yılı aşkın devam eden savaş dönemi Anadolu'yu çok sarsmıştı. Çalışma çağındaki genç nüfusun cephelerde can vermesi, Batı Anadolu'nun işgali sonucu topraklarından göç eden, varlıkları ellerinden alınan, üretim araçları tahrip edilen köylülerin üretemez hale gelmesi tarım kesimini olumsuz etkilemişti. Bütün bu olumsuzluklara Anadolu tarımının geleneksel yapısal sorunları da eklendiğinde Cumhuriyet ilan edildiğinde ülke ekonomisinin en önemli sektörü hiç de iç açıcı durum arz etmiyordu. ${ }^{5}$ Bununla birlikte Türk iktisadi hayatında önemli bir yer işgal eden ziraat, Cumhuriyet döneminde de bu önemini muhafaza etmiş ve Türk iktisadının temel alanlarından biri olmuştur. Çalışmamızın dayanağını oluşturan raporlarda da Cumhuriyetin ilanından sonra zirai durum ve gelişmelere önemli yer verilmiştir. 1929 dünya ekonomik krizi ve bunun Türkiye'ye etkilerini ortaya koymak amacıyla hazırlanan iki ayrı raporda özellikle 1929 yılına kadar olan zirai durum ve buna dayalı ihracat ile ilgili önemli tespitler bulunmaktadır. Türkiye'nin bir tarım ülkesi olduğuna dikkat çekilen raporlarda başta hububat olmak üzere tütün, pirinç, pamuk gibi başlıca zirai faaliyetler ile ilgili ayrıntılı bilgiler verilmiştir. 1929 yılına ait iktisadi raporda yer alan bilgiler 1şı̆̆ında Cumhuriyet'in özellikle ilk yıllarında üretimi hızla artan zirai ürünler arasında buğdayın önemli bir yer tuttuğu görülmektedir. Nitekim 1928 yılında Türkiye'deki buğday üretimi takriben 1.600 .000 ton iken bu rakamın 1929 yılında 2.000 .000 tona ulaştığı tespit edilmektedir. 1929 y1lı itibariyle Türkiye'de 21.000.000 dönüm buğday ekili arazi olduğu da raporda belirtilen önemli bir husustur. Aynı yıl itibariyle Türkiye'de ekili toplam arazinin 40.230.000 dönüm olduğu dikkate alınırsa Cumhuriyet döneminde zirai ürünlerin içinde buğdayın oldukça önemli bir yer tuttuğu söylenebilir. ${ }^{6} 1929$ iktisadi bunalımının üretimini olumsuz ölçüde etkilediği ürünlerin başında da buğday gelmiştir. 1929 bunalımı dolayısıyla buğday fiyatlarında hissedilir ölçüde düşüş yaşanmış ve özellikle bu durum buğday üreticisi köylüyü olumsuz etkilemiş ve birçok değirmen zarar etmiştir. Aynı zamanda buğday üretiminde de gözle görülür azalma yaşanmış hatta Türkiye 1929 yılı içerisinde Amerika, Romanya ve Macaristan'dan önemli miktarda buğday ithal etmek zorunda kalmıştır. Buğdayın yanı sıra mısır da üretim itibariyle zirai faaliyetler içinde önemli yer tutan bir mahsul olmuştur. Özellikle İzmir, Adapazarı ve Bandırma havalisinde yetiştirilen mısırın kalite itibariyle Trabzon ve Samsun havalisindekine göre çok daha iyi olduğu raporlarda dikkat çekilen hususlardan biri olmuştur. ${ }^{8}$ Cumhuriyetin ilk yıllarında gerek üretim ve gerekse ihracattaki payı itibariyle son derece önemli mahsullerden biri de tütün olmuştur. Türkiye'de üretilen tütün miktarı 1927 y1lında 56.150 .000 kilo, 1928 yılında 41.9000 .000 kilo ve 1929 yılında ise 35.845.000 kilo olarak gerçekleşmiştir. Üretimin giderek azalmasında 1929 buhranının önemli bir payı olmakla birlikte ayrıca hava şartları ve tütün üretimi ile ilgili olarak getirilen bazı sınırlamalar da üretimin düşmesine neden olmuştur. ${ }^{9}$ Bununla birlikte ihracat malları içinde tütün oldukça önemli bir yere sahip olmuştur. Mesela 1927 yılı ihracatında 44 milyon lira kıymetinde ve 29.4 milyon kilo değerinde tütün ihraç edilirken; 1928 yılında 54 milyon lira kiymetinde ve 39.8 milyon kilo; 1929 yilında 40.9 milyon lira kıymetinde ve 32.8 milyon kilo ve 1930 yılında 43.1 milyon lira kıymetinde ve 32.9 milyon

\footnotetext{
${ }^{5}$ Tevfik Çavdar, Türkiye Ekonomisinin Tarihi (1900-1960), İmge Kitabevi, Ankara, 2003, s. 181.

${ }^{6}$ BCA, 030.10/166.154.7, s. 13-14.

${ }^{7}$ BCA, 030.10/166.154.7, s.14.

${ }^{8}$ BCA, 030.10/166.154.7, s.14.

${ }^{9}$ BCA, 030.10/166.154.7, s.15.
} 
kilo tütün ihracı gerçekleştirilmiştir. ${ }^{10} 1929$ yılında Türkiye 4.2 milyon kilo ile en fazla Almanya ve Amerika Birleşik Devletlerine tütün satışında bulunmuştur. Alım satım işlemleri büyük ölçüde reji idaresi ve bir kısım yabancı tüccarlar tarafında yapılan tütün üretimi ile ilgili olarak 1929 yılında Ziraat Vekaleti tarafindan 113 maddelik Tütün İşleri adıyla bir kanun da hazırlanarak, ekiminden yetiştirilmesine ve kurutulmasına dair önemli düzenlemeler yapılmıştır. ${ }^{11}$ Cumhuriyetin ilk yıllarında üretim eksikliğinden dolayı büyük miktarlarda ithalatının yapılmak zorunda kalındığı ürünlerden biri olan pirincin üretiminin arttırılması amacıyla oldukça önemli tedbirlerin alındığı raporlardan anlaşılmaktadır. Sadece 1925 yılında Türkiye'nin 2.6 milyon Türk lirası kıymetinde pirinç ithal ettiğine dikkat çekilen raporda pirinç üretiminin arttırılmasına yönelik olarak hükümet tarafından 1929 yılında İtalya ve Fransa'dan uzmanlar getirtildiği, Adana ve civarında pirinç üretimi ile ilgili çalışmalar yaptırıldığ 1 ve bu tedbirler neticesinde 1929 yılında pirinç üretiminde ciddi artışların görüldüğü ifade edilmiştir. ${ }^{12}$ İncir, Cumhuriyetin ilk y1llarında hem üretim itibariyle hem de ihraç maddesi olması itibariyle önemli bir zirai ürün olmuştur. 1928 yılında 35 bin ton incir üretilmiş ve kuru meyve kapsamında ülkenin ihracatında önemli bir yer almıştır. Mesela sadece 1929 yılı ortaları itibariyle 19.8 milyon kilo incirin ihraç edildiği anlaşılmaktadır. ${ }^{13}$ İncirden başka kuru üzüm de önemli üretim maddelerinden biri olmuştur. 1928 yılında 40 bin ton olarak gerçekleştirilen kuru üzüm üretimi 1929 yılında 78 bin tona ulaşmış ve Türkiye ihracatında önemli bir yer tutmuştur. Mesela sadece 1929 yılında 34 milyon tonalite kuru üzüm ihracatı gerçekleştirilmiştir. ${ }^{14}$ Cumhuriyetin ilk yıllarında başta hava şartlarının müsaitsizliği olmak üzere değişik nedenlerden dolayı üretiminde sıkıntı yaşanan mahsullerden biri fındık olmuştur. Karadeniz bölgesinde üretilen en önemli mahsul olan fındık, 1927 yılında bir milyon kantar olarak gerçekleşirken bu rakam 1928 yılında 350 bin kantara gerilemiştir.1929 yılında ise fındık üretimi 100 bin kilo yani 2500 sandık olarak gerçekleşmiştir. Fındık üretiminde görülen düşüşün sebebi sadece hava şartları ve Karadeniz sahilinde görülen bazı hastalıklar değil aynı zamanda son zamanlarda Karadeniz çiftçisinin afyon üretimine daha fazla ağırlık vermiş olmasıdır. ${ }^{15}$ Bununla birlikte kuru meyve tüm üretim sıkıntılarına rağmen ülkenin ihracatında Cumhuriyetin ilk yıllarında önemli yer tutmuştur. Nitekim 1927 yılında 25.5 milyon Türk lirası kıymetinde 113.8 milyon kilo; 1928 yılında 34.3 milyon Türk lirası kıymetinde 118.4 milyon kilo; 1929 yılında 23.9 milyon Türk lirası kıymetinde 100.7 milyon kilo ve 1930 yılında 27.3 milyon Türk lirası kıymetinde ve 104.5 milyon kilo miktarında kuru meyve ihracatı gerçekleştirilmiştir. ${ }^{16}$ Zeytin Cumhuriyetin ilk yıllarında üretim itibariyle fazla sorun yaşamayan fakat 29 bunalımının etkisiyle fiyatı en fazla düşen mahsullerden biri olmuştur. 1929 yılında kilosu 14 kuruşa kadar gerileyen zeytin Ayvalık, Mudanya ve Erdek civarında üretimi en fazla yapılan ürün olmuştur. ${ }^{17}$ Üretimi oldukça iyi olmak üzere benzer şekilde 1929 yılı itibariyle fiyatlarında en fazla düşüş yaşanan mahsulden biri de pamuktur.1929 y1lı itibariyle pamuk üretimi Adana ve çevresinde 130 bin balya, İzmir ve çevresinde ise 40 bin balya olarak gerçekleşmiştir. Pamuk fiyatlarının düşmesinde dünyada pamuk üretiminin son yıllarda fazla olarak gerçekleşmesinin önemli etkisi olmuştur. Ayrıca, Türkiye'de üretilen pamuğun nitelik itibariyle dünya pazarlarında rekabet edememesi ve sadece iç tüketimde kullanılması da fiyatlar üzerinde rol oynayan faktörlerdendir. ${ }^{18}$ Üretimi oldukça yüksek

${ }^{10}$ BCA, 030.10/26.182.9, s.14.

${ }^{11}$ BCA, 030.10/166.154.7, s.16.

${ }^{12}$ BCA, 030.10/166.154.7, s.16.

${ }^{13}$ BCA, 030.10/166.154.7, s.18

${ }^{14}$ BCA, 030.10/166.154.7, s.18.

${ }^{15}$ BCA, 030.10/166.154.7, s.19.

${ }^{16}$ BCA, 030.10/26.182.9, s.14.

${ }^{17}$ BCA, 030.10/166.154.7, s.20.

${ }^{18}$ BCA, 030.10/166.154.7, s.20. 
olmakla birlikte üreticinin kredi ile desteklenememesi ve bu nedenle mahsulün toplanarak pazara sevki noktasındaki sorunlardan dolayı fiyatları düşen bir diğer ürün ise portakaldır. Nitekim 1928 yılında 26 milyon kilo olarak gerçekleşen portakal üretiminin 1929 yılında iki katına çıkarak 60 milyon kiloya ulaştığı görülmektedir. ${ }^{19}$

Genel olarak Cumhuriyetin özellikle ilk yıllarında ziraatın gelişimi başta hava şartları, üreticinin yeterince kredi yoluyla desteklenememesi ve özellikle de 1929 bunalımı sonrasında uluslar arası konjonktürün müsaitsizliği gibi nedenlerden dolayı oldukça sorunların yaşandığı bir iktisadi alan olmuştur. Özellikle bazı ürünlerin krediye uygun nitelikte olmaması ve bu nedenle çiftçinin yeterli parayı bulamaması, bazı ürünlerin uluslararası pazarlarda rekabet gücünün olmayışı ve yine özellikle tarım alanında çalışan bazı amelelerin gelirin düşüklüğü nedeniyle demiryolları ve şose yapımında çalışmayı tercih etmeleri özellikle zirai üretimin düşmesinde etkili olmuştur. ${ }^{20}$ Nitekim 1929 y1lı itibariyle zirai mahsuldeki olumsuz durum nedeniyle bu alandaki ihracat gelirleri oldukça azalmış ve 20 milyon Türk lirası değerinde bir ihracat açı̆̆ı meydana gelmiştir. Ziraat alanındaki bu olumsuzlukların Türkiye iktisadı açısından ortaya çıkardığı menfi durum hükümetin aldığı bazı tedbirlerle ortadan kaldırılmaya çalışılmıştır. Başta köylü ve çiftçilerin eğitilmesi ve bilinçlendirilmesi, çiftçiye yeni tarım araç ve gereçlerinin sağlanması, gübre desteğinin sağlanması, tohumların 1slahı için tecrübe istasyonlarının teşkil edilmesi ve kredi desteği verilmesi bu tedbirlerin başında gelmiştir. ${ }^{21}$

\section{Sanayi}

Cumhuriyet'in ilanından sonra özellikle 1930'lu yılların başına kadar Türkiye'de sanayi diğer sektörlere göre çok daha geri durumdaydı. Osmanlı sanayisinin yapısal mirasının korunduğu Cumhuriyet'in ilk yıllarında devletin sanayi yatırımları oldukça zayıf ve sınırlıydı. Sanayi ve Maadin Bankası'nın faaliyetlerinin son bulduğu 1932 yılında Bankaya ait ve hepsi Osmanlı döneminden devralınmış sadece dört fabrika bulunuyordu. ${ }^{22} \mathrm{Bu}$ itibarla Cumhuriyetin ilk yıllarında en büyük mücadelenin verildiği sektör sanayi olmuştur. Atatürk döneminde hazırlanan iktisadi raporlarda sanayi alanındaki gelişmelere dair bilgiler de geniş yer tutmaktadır. 1938 tarihinde hazırlanmış olan ve 1923-1938 yıllarını kapsayan 15 yıllık zamanda Türkiye'nin iktisadi ve ticari gelişimini rakamlarla detaylı bir şekilde ortaya koyan raporda, geçmişe kıyasla Cumhuriyetin özellikle sanayi alanında oldukça önemli değişimlere öncülük etiğine dikkat çekilmektedir. 1913 yılında İttihat ve Terakki idaresi tarafından çıkarılan Teşvik-i Sanayi Kanununa rağmen Osmanlı İmparatorluğu döneminde sanayi alanında kayda değer bir gelişmenin olmadığının altı çizilen raporda, 1915 yılında Osmanlı'da sanayinin 264 müessese, 14.060 işçi, 379 motor adedi, 20.977 beygir kuvveti ve 7.570 .000 Türk lirası istihsal ve imalat ile oldukça vasat durumda olduğu belirtilmektedir. ${ }^{23}$ Bununla birlikte Cumhuriyet döneminde sanayiye büyük önem verildiği, Atatürk'ün "Endüstrileşmek, en büyük milli davalarımız arasında yer almaktadır. Çalışması ve yaşaması için ekonomik elemanları memleketimizde mevcut olan büyük küçük her çeşit sanayi kuracağız ve işleteceğiz. En başta vatan müdafaası olmak üzere, mahsullerimizi kıymetlendirmek ve en kısa yoldan en ileri ve refahlı Türkiye idealine ulaşabilmek için, bu bir zarurettir." Sözleriyle dikkat çekilen raporda sanayinin bağımsız Cumhuriyet için en önemli unsur olduğuna da vurgu

\footnotetext{
${ }^{19}$ BCA, 030.10/166.154.7, s.20.

${ }^{20}$ BCA, 030.10/166.154.7, s.10.; 1929 Dünya ekonomik krizinin Türkiye ekonomisi üzerindeki olumsuz etkileri için bkz. Ramazan Kurtoğlu, Türkiye Ekonomisi (1838-2010), Orıon Kitabevi, Ankara,2015, s. 327-331.

${ }^{21}$ BCA, 030.10/166.154.7, s.11-12.

${ }^{22}$ Korkut Boratav, Türkiye İktisat Tarihi (1908-1985), Gerçek Yayınevi, İstanbul, 1998, s. 49-50.

${ }^{23}$ BCA, 490.01/1455.38.2, s.40.
} 
yapılmıştır. ${ }^{24}$ Söz konusu rapora göre Atatürk döneminde sanayi alanında "yapmak ve yaptırmak" esası kabul edilerek uygulandığı altı çizilen en önemli husustur. "Yaptırmak" ilkesi çerçevesinde bu dönemde devlet özel sermayeye sanayide geniş bir saha bırakmış ve hatta özel teşebbüsü bütçeden desteklemiştir. Nitekim bu çerçevede 1927 yılında çıkarılan Teşvik-i Sanayi Kanunu ile birçok müsaade ve muafiyetler sağlanmak suretiyle söz konusu destek verilmiştir. ${ }^{25}$ Bundan başka yerli mahsul ile yerli mamulatın himayesini temin etmek amacıyla 1929 yılında gümrük tarifesi kabul edilerek uygulanmaya başlanmıştır. Hatta bedelleri hükümet bütçesinden ödenen her çeşit giyeceklerin yerli malı olması mecbur edilmesiyle bu teşvik ve himaye çok daha genişletilmiş̧ir. Ayrıca yerli malının kalitesinin arttırılması maksadıyla önemli bazı normlar kabul edilmiştir. Yine yerli malın daha ucuz hale getirilmesi için maliyeti arttıran bazı vergilerde önemli indirimlere de gidilmiştir. Bunlarla da yetinilmeyip sanayinin millileştirilmesi ve güçlendirilmesi amacıyla yabancı uzmanların yerleri Türk uzmanların getirilmesini teşvik eden yasalar kabul edilmiş ve hatta uzman sıkıntısı çekilen alanlarda yetiştirilmek üzere Avrupa'ya öğrenci gönderilmesine önem gösterilmiştir. ${ }^{26}$ Ayrıca hükümet, sanayiyi teşvik ve takviye etmek için sırf iç üretime münhasır olarak İstanbul ve Ankara'da sergiler açmıştır. Yerli malını teşvik açısından son derece faydalı olan bu sergiler sanayiyi teşvik anlamında önemli rol oynamıştır. ${ }^{27}$

Cumhuriyet döneminde alınan bu tedbirler sayesinde Teşvik-i Sanayi Kanunundan istifade edilerek 1938 yılı itibariyle geldiği nokta 1394 adet sanayi müessesesi kurulmuş, 100.598 iş̧̧, 262.726 beygir kuvveti ve 285.008.000 Türk lirası kıymetinde istihsal ve imalat olmuştur. ${ }^{28}$ Raporda yer verilen rakamlar dikkate alındığında imparatorluk dönemine göre sanayi alanında ciddi bir ilerlemenin olduğu görülmektedir. Bu durum üzerinde Cumhuriyetin ilk yıllarından itibaren alınan tedbirlerin önemli etkisi olduğu tartışılmazdır. Nitekim daha 1924 yılında gerek kurulması icap eden endüstrinin mahiyeti ve gerekse buna ayrılacak sermayenin büyüklüğü bakımından bazı önemli sanayi tesislerini memlekette kurmak görevini üstlenmiş olan hükümet bu çerçevede Sanayi ve Maadin Bankasını kurmuş ve bu banka aracılığıyla Hereke, Bakırköy, Feshane Mensucat fabrikaları ile Beykoz Deri ve Kundura Fabrikalarını işlettiği gibi bunlara ilaveten Uşak Şeker Fabrikası ile Tosya ve Maraş Çeltik Fabrikalarını da işletmeye açmıştır. ${ }^{29} 3$ Haziran 1933 tarihinde T.B.M.M'nin kabul ettiği bir kanun ile 20 milyon lira sermaye ile kurulan Sümerbank Sanayi ve Maadin Bankasının yerini almıştır. Söz konusu bankanın sermayesi 1938 yılında 80.5 milyon liraya ulaşmıştır.Sümerbank'ın kurulmasından hemen sonra hazırlanan birinci beş yıllık sanayi programının uygulama vazifesi de bu bankaya verilmiştir. ${ }^{30}$

Birinci beş yıllık sanayi programı Türkiye'de sanayi alanında hızlı bir gelişmenin temelini teşkil etmiş̧ir. Nitekim bu program çerçevesinde dokuma endüstrisi (pamuk, kendir, yün), maden endüstrisi (demir, sömikok, kömür, bakır, kükürt), selüloz endüstrisi (selüloz, kağıt, karton, sun'i ipek), Seramik sanayi (şişe, cam, porselen), kimya sanayi(zaçyă̆ sudkostik, süperfosfat) gibi alanlar başlıca sanayi şubeleri olarak kabul edilmiştir. ${ }^{31}$ Zira söz konusu sanayi kolları dışarıdan en fazla ithalatının yapıldığı alanlar itibarıyla önem arz etmektedir. Söz konusu sanayi alanlarından senelik yapılan ithalatın kıymetleri, dokuma sanayi yıllık ithalat değeri 47 milyon lira, maden sanayi 13 milyon lira, selüloz sanayi 5 milyon lira,

${ }^{24}$ BCA, 490.01/1455.38.2, s.41.

${ }^{25}$ BCA, 490.01/1455.38.2, s.41.

${ }^{26}$ BCA, 490.01/1455.38.2, s.42.

${ }^{27}$ BCA, 030.10/166.154.7, s.27.

${ }^{28}$ BCA, 490.01/1455.38.2, s.43.

${ }^{29}$ BCA, 490.01/1455.38.2, s.43-44.

${ }^{30}$ BCA, 490.01/1455.38.2, s.44.

${ }^{31}$ BCA, 490.01/1455.38.2, s.44. 
seramik sanayi 4 milyon lira, kimya sanayi 6 milyon lira olarak gerçekleştiğine dikkat çekilen raporda beş yıllık sanayi programının ithalatın toplamda 75 milyon lira değerinde ve ithalatın \% 43 lük bir oranına tekabül eden önemli bir sanayi açığını bu suretle yerli üretimle karşılanmasını öngördüğü vurgulanmıştır. ${ }^{32}$ Tesisatı, inşaatı ve dolaşımdaki sermayesiyle 90 milyon liraya mal olan birinci beş yıllık sanayi programının gerek devletin mali ve gerekse para politikası üzerinde baskı unsuru olmadan başarıyla tamamlandığına da raporda dikkat çekilmiştir. Zira 1938 yılı itibariyle söz konusu program sayesinde ithalatta \%30'luk bir azalma gerçekleşmiştir. ${ }^{33} 1938$ y1lı itibariyle Osmanlı dönemiyle bir mukayesesi yapıldı ğında Osmanlı döneminde mevcut sanayi müessesi sayısı 264 iken bu sayının 1938 yılında 1394'e çıktığı ve 1938'te kabul edilen ve uygulamaya konulan ikinci beş yıllık sanayi programı kapsamında da bu sayının 1429'a yükseleceği öngörülmüştür. ${ }^{34}$ İkinci beş yıllık sanayi programında ise şu sanayi kolları ele alınmıştır: madencilik, maden kömürü ocakları işletmeleri, mıntıka elektrik santralleri, ev mahrukatı sanayi ve ticareti, toprak sanayi, gıda maddeleri sanayi ve ticareti, kimya sanayi, mihaniki sanayi ve denizcilik. ${ }^{35}$

Cumhuriyet döneminde alınan tedbirler çerçevesinde birçok sanayi kolunda önemli gelişmelerin olduğu değişik raporlarda da tespit edilmiştir. Nitekim 1929 tarihli bir diğer raporda da bazı sanayi kollarındaki hızlı gelişme ayrıntılı bir şekilde ortaya konulmuştur. Mesela deri sanayi ve ipekli mensucat Türkiye'de Cumhuriyet döneminde oldukça gelişen birer sanayi kolu olmuştur. Daha çok İstanbul'da bulunan deri fabrikaları ürettikleri mallarıyla Avrupa ile rekabet edecek duruma gelmişlerdir. ${ }^{36}$ Yine hızla gelişen ve oldukça önem verilen bir diğer sanayi de ipek sanayi olmuştur. Çok eski zamanlardan beri Türkiye'de, özellikle Marmara havalisinde önemli bir yer tutan ipekçilik, gerek harp ve gerek nüfus mübadelesi nedenleriyle oldukça gerileme göstermişti. Bununla birlikte özellikle Trakya ve Balkanlar'dan ve diğer bazı yerlerden mübadeleyle gelen nüfus daha önceleri tütün üretimiyle meşgul olmalarına rağmen hükümet tarafından ipek sanayini geliştirmek amacıyla ipek üretiminin yapıldığı yerlerde iskan edilmiştir. Hatta ipekçiliğin gelişmesi için Rusya'dan da uzmanlar getirtilmiş ve bunlar vasıtasıyla buradaki halk eğitilmiştir. Böylece Türk ipeğinin değeri Bağdat ipeğinin değerine varmıştır. Nitekim alınan tedbirlerle ipek üretimindeki hızlı artış ipek ithalatında önemli ölçüde azalma sağlamıştır. 1928 yılında Türkiye'nin ipekli mamul ithalatı 216.372 kilo iken bu rakam 1929 yllında 189.111 kiloya gerilemiştir. ${ }^{37}$ Konserve sanayi ise fazla bir gelişme gösterememiştir. Bununla birlikte biri Edirne, biri Bursa ve diğer yedisi İstanbul'da olmak üzere 9 konserve fabrikası bu alanda faaliyet göstermiștir. Hatta Türkiye'den Fransa, Belçika, Mısır ve İngiltere'ye Cumhuriyet döneminde önemli miktarda konserve ihraç edilmiştir. ${ }^{38}$ Atatürk döneminde şeker sanayi hızla gelişen alanlardan bir diğeridir. Özellikle Macarlar tarafindan işletilen Alpullu Şeker fabrikası bu dönemde şeker sanayinin önemli bir gücü olmuştur. Zira sadece 1928 yılında Alpullu Şeker Fabrikasında üretilen şeker 4840 ton olarak gerçekleşmiştir.1926 yılında kurulan Uşak Şeker Fabrikası da bu dönemde şeker üretiminin artmasında önemli rol oynamıştır. Bununla birlikte Atatürk döneminde ithal edilen ürünler içinde şeker yerini korumuştur. Zaman zaman hükümet, şeker üretimini arttırmak ve ithalatını azaltmak amacıyla Çin, Mısır, Cava ve Amerika'dan şeker

\footnotetext{
${ }^{32}$ BCA, 490.01/1455.38.2, s.45.

${ }^{33}$ BCA, 490.01/1455.38.2, s.45.

${ }^{34}$ BCA, 490.01/1455.38.2, s.45.

${ }^{35}$ BCA, 490.01/1455.38.2, s.46.

${ }^{36}$ BCA, 030.10/166.154.7, s.29.

${ }^{37}$ BCA, 030.10/166.154.7, s.29.

${ }^{38}$ BCA, 030.10/166.154.7, s.30.
} 
kamışı dahi getirme yoluna gitmiştir. ${ }^{39}$ Şeker sanayinin yanında ispirto ve kibrit sanayi de bu dönemde hızla gelişen sanayi kollarındandır. Atatürk döneminde en fazla gelişme kaydeden sanayi alanı mensucat sanayi olmuştur. Hükümetin aldığ ilgili uygulamaların bu sanayin gelişiminde etkisi fazlaca olmuştur. Özellikle Sanayi ve Maden Bankasının destekleri sayesinde bu alandaki üretim oldukça artmıştır. Bununla birlikte mensucat sanayi bu dönemde dahili ihtiyacı karşılama noktasına gelememiştir. ${ }^{40}$ Nitekim 1928 yılında dokuma sanayinin gelişmesi maksadıyla Türk ve Japon sermayesiyle Bursa'da gelişmiş bir ipek fabrikasının kurulmasına destek verilmiştir. ${ }^{41}$ Ayrıca bu dönemde hızla fabrikalaşmaya ağırlık verilmiştir.1928'de Bakırköy Çimento fabrikasının inşaatına başlanırken, 1929 yılında yine Bakırköy'de bir gramofon fabrikası, İstanbul'da margarin ve pamuk fabrikaları ve Gemlik’te karton fabrikasının da inşaatına başlanmışıtır. ${ }^{42}$

\section{Ticaret}

Atatürk döneminde ticaretin geliştirilmesi ve özellikle dış ticarette ihracatın arttırılması amacına yönelik önemli tedbirler alınmıştır. ${ }^{43} \mathrm{Bu}$ dönemde özellikle dış ticareti milli korunma siyasetine uygun olarak geliştirmek amaciyla 28 Kasım 1934 tarihinde İktisat Vekaletine bağlı olarak Türkofis adıyla bir teşkilat kurmuştur. Türkiye Dış Ticaret İşleri Milli Ofisleri Dairesi'nin kısa adı olan Türkofis, daha önce dış ticaret ile ilgili olarak çalışan Beynelmilel Ticaret Mukaveleleri, Harici Ticaret Müdürlügüü, Takas Komisyonu, Konjonktür Bürosu, İstanbul İhracat Ofisi, Ecnebi Memleketler Ticaret Mümessillikleri adlarıyla faaliyet göstermiş olan bazı kurumların vazifesini üstlenmek üzere kurulmuştur. ${ }^{44}$ Dış ticareti geliştirmek maksadıyla kurulan Türkofis'in başlıca görevleri şunlardı: 1. İstihbarat, neşriyat, propaganda, sergi ve panayır işleri 2. Alıcı piyasaların ihracat mallarımızın tetkiki ve tavassut işleri 3 . Ticaret ve tediye anlaşmaları hazırlıkları 4. Milli korunma ve dış ticarette güdümlü ekonomi tatbikatı. ${ }^{45}$ Türkofis bir reis, iki reis yardımcısının idaresinde merkezde politika ve maddeler dairelerinde ve ülke içinde 5, dünyanın değişik ülkelerinde bulunan 16 şubeden ibaret bir teşkilat olarak yapılandırılmıştır.Atatürk döneminde ithalat ve ihracatta özellikle 1929 buhranı sonrasında dahil olunan kliring sisteminin önemli etkisi olmuştur. Kaldı ki bu dönemde Türkiye'nin ithalat ve ihracatının hemen hemen \% 90'ı kliring sistemin dahil olduğu ülkelerle yapıldığı raporlarda dikkat çeken hususlardandır. Bu sistem sayesinde başta paranın değeri korunmuş aynı zamanda iktisadi alanda sistemli ve bir metot dahilinde önemli gelişmeler sağlanmıştır. Nitekim 1933-1938 yılları arasında gerçekleşen ithalat ve ihracat rakamları bu durumu çok açık bir şekilde göstermektedir:

1933-1937 yılları arasında 5 yı1lık ithalat ve İhracat aşağıdaki gibi olmuştur: ${ }^{46}$

\begin{tabular}{|c|c|c|c|c|}
\hline Y11 & İthalat & İhracat & Fark & D1ș Ticaret Toplamı \\
\hline 1933 & 74.676 & 96.162 & $\overline{21486}$ & 170.838 \\
\hline 1934 & 86.790 & 92.149 & 5.359 & 178.939 \\
\hline 1935 & 88.823 & 95.861 & 7.038 & 184.684 \\
\hline 1936 & 92.531 & 117.733 & 25.202 & 210.264 \\
\hline
\end{tabular}

${ }^{39}$ BCA, 030.10/166.154.7, s.31.

${ }^{40}$ BCA, 030.10/166.154.7, s.32.

${ }^{41}$ BCA, 030.10/166.154.7, s.33.

${ }^{42}$ BCA, 030.10/166.154.7, s.33.

43 Atatürk dönemi dış ticaret alanındaki gelişmeler hakkında ayrıntılı bilgi için bkz. Yahya S. Tezel, Cumhuriyet Döneminin İktisadi Tarihi, Tarih Vakfı Yurt Yayınları, İstanbul, 2002, s. 113-115.

${ }^{44}$ BCA, 490.01/1455.38.2, s.4.

${ }^{45}$ BCA, 490.01/1455.38.2, s.5.

${ }^{46}$ BCA, 490.01/1455.38.2, s.5. 
Mehmet AYDIN

\begin{tabular}{lllll}
\hline 1937 & 114.379 & 137 & 984 & 23.605 \\
252.363 & & & &
\end{tabular}

$\mathrm{Bu}$ verilerden de anlaşılacağ $\mathrm{u}$ üzere 1930'lu y1llarda ihracatta önceki dönemlere nazaran önemli bir gelişme olduğu görülmektedir. Nitekim bunda 1930 yılına kadar ihracatı düzene sokacak ve geliştirecek yasal düzenlemelerin yapılmamış olmasının önemli bir rolü vardır. Nitekim 19 Haziran 1930 tarihinde neşredilen “Ticarette Tağşişin Men'i ve İhracatın Murakebesi ve Korunması Hakkında Kanun" ile dış ticaretin ıslahı hususunda ilk adım atılmış ve önemli ihracat maddelerinden olan findık ve yumurta ihracatını arttırmak amaciyla önemli tedbirler alınmıştır. Hatta findık ve yumurta kontrolü ile ilgili hazırlanan yasa da bu kanuna ilave edilmiştir. Ayrıca çekirdeksiz kuru üzüm ve palamut nizamnameleri de hazırlanarak uygulamaya konulmuştur. ${ }^{47} \mathrm{Bu}$ kanunların amacı Türk mallarının daha kaliteli ve fennin gerekleri çerçevesinde uygun tarzda ihraçlarını sağlamak ve bu suretle ihracatı geliştirmekti. Böylece Türk mallarının dünya piyasalarında rekabet gücü de arttırılmış oluyordu.

1930 yılından önceki dönemlerde ise ihracatın ithalat karşısında oldukça geride olduğu raporlarda belirtilen önemli hususlardan biridir. Nitekim 1929 tarihli raporda Türkiye'nin ihracatının 173.537.489 Türk lirası değerinde olmasına karşılık ithalatının ise 223.531.775 Türk lirası değerinde gerçekleştiğine vurgu yapılmıştır. ${ }^{48}$ Aynı raporda 1928 yılında Türkiye'nin ithalat ve ihracatı şu şekilde belirtilmiştir: ${ }^{49}$

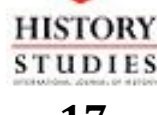

17

Volume 9

Issue 3

September 2017
Esvanın Cinsi İthalat Miktarı

Canlı hayvanat 281.003.

Balık vesaire $\quad 1.506 .606$

Hububat $\quad 70.191 .018$

Sebze ve Meyve 12.758.778

Şekerli mevad 72.278 .466

Maden suyu sirke1.487.796

Nebatlı yağlar 8.447 .476

Tütün ve tömbeki164.511

Tohum vesaire 2.228 .596

Deri $\quad 3.394 .308$

Gübreler $\quad 795.846$

Ağaç mahsulatı 10.064.759

Kağıt ve mamulatı23.326.172

Pamuk

297.104

Kınnap kenevir 8.601.947

Yün, yün kumaş3.261.258

İpekli kumaş 378.093

Hazır elbise 2.601.065

Mevaddı şahmiye45.126.623

Madeniyat $\quad 175.191 .846$

Makine ve teferruat113.685.659

Araba, vapur, vagon9.459.443

Saat ve musiki alet1.233.450

Yağ, mum,sabun101.359.809
Kiymeti

1.381 .637

8.763 .597

2.785 .598

20.453 .661

474.615

3.550 .453

896.233

240.631

6.121 .256

76.313

1.965 .000

5.383.532

52.449 .271

5.001 .593

15.767 .230

3.960 .816

4.497.140

6.661 .316

25.876 .724

10.462 .824

8.128 .376

4.050.081

11.185 .352

\begin{tabular}{l} 
İhraç miktarı \\
\hline 338.239 \\
1.6668 .407 \\
64.468 .576 \\
116.489 .412 \\
291.094 \\
$\quad 6.279$
\end{tabular}

2.364.830

39.856 .957

52.665 .012

1.457 .100

2.212.226

70.259 .443

3.279 .956

14.784 .909

462.977

11.628 .071

606.423

21.624

4.029.996

46.233 .170

323.804

62.860

29.961

397.486
Kiymeti

2.707 .476

7.601 .853

6.147 .028

34.321 .343

106.609

1.072

1.475 .484

54.197 .143

4.709 .30

3.563.683

22.890

3.189 .664

296.766

10.320 .476

167.491

18.500 .063

2.294.349

22.746

210.186

3.738.871

229.978

128.063

95.279

61.781

${ }^{47}$ BCA, 490.01/1455.38.2, s.6.

${ }^{48}$ BCA, 030.10/166.154.7, s.40

${ }^{49}$ BCA, 030.10/166.154.7, s.41. 


\begin{tabular}{llllll} 
Mevaddı müşteile1.245.448 & 572.281 & 64 & \multicolumn{1}{c}{50} & \\
Boza ecza vs & 7.157 .835 & 407.340 .206 & 10.613 .226 & \\
Diğer bazı eşya 6.402 .041 & 4.716 .163 & 19.577 .498 & 890.786 \\
Toplam $\quad 25.493 .733$ & 223.531 .776 & 626.054 .534 & 689.537
\end{tabular}

Yukarıdaki verilerden anlaşılacağı üzere 1920'li yıllarda Türkiye'nin ithalatının ihracata nazaran oldukça yüksek gerçekleştiği görülmektedir. Buna göre ithalat maddeleri arasında canlı hayvanatın kıymeti ithalat toplamının \% 2.16'sını teşkil etmiş̧ir. Hububatın fazla ithal edildiği dikkat çekmektedir. 1928 y1lı içinde 46.557 ton buğday ithal edilmiş olup bunun değeri 5.174.522 lira olmuştur. Bunlardan başka 1920'li yıllarda arpa ve misır ithali önemli miktarlarda gerçekleşmiştir. Patates bu yıllarda en fazla ithal edilen ürünlerden olmuştur. 1929 yılında hububat ithalatı kıymet itibariyle ithalat toplamının \%4 'ünü teşkil etmiştir. Çay ve kahve ile şeker ve çikolata gibi maddelerin ithalattaki payı ise 1928 yılında \% 9.15 olmuştur. 1928 yılında takriben 13 milyon liralık şeker ithal edilmiştir. Bu yıllarda şeker daha çok Çekoslovakya, Rusya ve Bulgaristan'dan ithal edilmiştir. 1928 yılında çay ithali önemli bir artış göstermiştir. Bununla birlikte aynı yıl ispirto ve ispirtolu meşrubatın ithalinde büyük azalma görülmüştür. Hububat tohumu ve çiçek tohumlarının ithalatı artmış ve 1928 yılında 85.000 Türk lirasına varmıştır. Deri ürünlerinde ise bir artış olmamıştır. Kereste ithali ise oldukça düşük kalmıştır. Kağıt ve kağıt ürünlerinin toplam ithalat içinde yeri 1928 yılında \% 2.4 oranında gerçekleşmiştir. ${ }^{50}$ Türkiye ithalatında söz konusu yıllarda ağırlığı pamuk ithali teşkil etmiştir. Nitekim 1928 yılında takriben 52.2 milyon lira kıymetinde pamuklu eşya ithal edildiği görülmektedir. Yün ve yünlü eşyanın ithalinde ise 1928 yılında önceki yıllara nazaran bir düşüş olmuştur. Nitekim 1926 yılında 14 milyon kıymetindeki yün ve yünlü eşyanın 1928 yılında ithalatı 9.5 milyon lira olarak gerçekleşmiştir. Kauçuklu eşyanın ise ithalatında artı̧̧ görülmüştür. Mesela 1927 yılında bunların kıymeti 3.5 milyon lira iken 1928 yılında 4.5 milyon liraya yükselmiştir. Çimento ithalinde de önemli bir azalma yaşanmıştır. Yine demiryolu çubuk ve traverslerinin ithalinde de önemli azalma olduğu raporlarda tespit edilmektedir. Cumhuriyetin ilk yıllarında ithalata nazaran oldukça geri olan ihracatta da özellikle bazı maddelerin ihracında önemli artışların olduğu raporlarda tespit edilen hususlardan biri olmuştur. Nitekim 1920'li yıllarda ihracatı giderek artan maddelerden biri yumurta olmuștur. Mesela 1926 yılında 9.5 milyon kıymetinde gerçekleșen yumurta ihracı 1928 yılında 11.5 milyon Türk lirasına yükselmiştir. ${ }^{51}$ Yine 1928 yılında üzüm, incir ve zeytin ihracında da önemli artış yaşanmıştır. 1927 yılında 7.5 milyon lira olarak gerçekleşen kuru üzüm ihracı 1928 yılında 15.2 milyon lira olarak iki misline çıkmıştır. İncir ihracında fazla bir artış olmamıştır. 1927 yılında 4.3 milyon lira olan incir ihracı 1928 yılında 4.8 milyon lira olarak gerçekleşmiştir.Bu yıllarda en kuvvetli ihraç maddesini tütün teşkil etmiştir. 1927 yılında 43.8 milyon lira olan tütün ihracı 1929 yılında ise 54.02 milyon lira olarak gerçekleşmiştir. Kenevir , haşhaş tohumu, tuzlanmış bağırsak, koyun ve kuzu derisi de 1928 yılında artış gösteren ihraç mallarından olmuştur. 1928 yılında yün ihracatı da 4.2 milyon kıymetinde olmuştur. Kömür ihracı 1926 yılında 222 bin ton iken 1928 y1lında 94 bin tona gerilemiştir. $\mathrm{Bu}$ da toplamda 2 milyon liralık bir farkın oluşmasına neden olmuştur. 1928 yılında Türkiye'nin en fazla ihracı Almanya ile olmuştur. Aynı yıl Almanya'dan Türkiye'nin ithalatı ise 31.9 milyon lira kıymetinde olmuştur. Fransa ve İngiltere de en fazla ithalatın yapıldığı ülkeler olmuştur. İtalya, Çekoslovakya, Belçika ve Amerika Birleşik devletleri de en fazla ithalatın yapıldığı ülkeler olmuştur. ${ }^{52} 1928$ yılında en fazla ihracatın yapıldığ

${ }^{50}$ BCA, 030.10/166.154.7, s.42.

${ }^{51}$ BCA, 030.10/166.154.7, s.43.

${ }^{52}$ BCA, 030.10/166.154.7, s.44-45. 
olmuştur. İtalya'dan başka Kuzey Amerika, İngiltere ve Macaristan da en fazla ihracın yapıldığ ülkelerdendir. $^{53}$

Atatürk döneminde ihracat ve ithalatın yanı sıra önemli sayıda ticari teşekkülün kurulduğu ve faaliyet gösterdiği raporlardan anlaşılmaktadır. 1923-1938 yılları arasında sermaye toplamı 128.903.990 lira değerinde 168 anonim şirketinin kurulduğu görülmektedir. Atatürk döneminde 18.157 .000 lira sermaye toplamıla 214 adet de limitet şirket faaliyet göstermiştir. ${ }^{54}$ Bunlardan başka 1.356 .344 lira sermayeli ve 16.552 ortaklı 67 kooperatif kurulmuştur. 1933 yılı itibariyle 2.239.927 lira sermayesiyle 71 yabancı şirket varken bu sayı 1938 yılında 103'e çıkmıştır. ${ }^{55} \mathrm{Bu}$ dönemde sigorta şirketlerinin de kurulduğu görülmektedir. Osmanlı İmparatorluğu döneminde daha çok ecnebi şirketlerin ellerinde bulunan sigortacılık bu dönemde kurulan Milli Reasürans Türk Anonim Şirketi'nin kontrolüne geçmiştir. Cumhuriyet devrinde açılan toplam 3.700 .000 lira sermayesiyle 8 sigorta şirketi bulunmaktadır. Cumhuriyet döneminde ticaretin gelişmesinde bankaların da rolü büyük olmuştur. Bu dönemde bankalar seri surette faaliyete geçmişlerdir. Cumhuriyetten önce banka sayıs1 11'di. Bu bankaların sermaye toplamı ise 44.768 .000 liraydı. Atatürk döneminde 32 yeni banka açılmıştır. Bu bankaların sermaye toplamı ise 284.160.000 lira olmuştur.

Sonuç itibariyle, Cumhuriyetin ilanından sonra takip edilen ekonomi politikaları

HISTORY STUDIES 19

Volume 9 Issue 3 September 2017 sayesinde iktisadi ve ticari hayatta Osmanlı dönemine nazaran oldukça hızlı bir gelişme yaşanmıştır. Başta tarım ve sanayi olmak üzere ticari hayat yeni dönemde alınan etkili tedbirler neticesinde oldukça gelişme kaydetmiştir. Söz konusu gelişmeler Atatürk döneminde hazırlanan bazı raporlarda ayrıntılı olarak ortaya konulmuş ve bu açıdan özellikle Cumhuriyet döneminin ekonomik tablosunu detaylı bir şekilde göstermesi açısından da ciddi bir kaynak vasfinı teşkil etmiştir.

\section{KAYNAKÇA}

\section{Arşiv Belgeleri}

-Başbakanlık Cumhuriyet Arşivi, 30.10/. 166.154.7

-Başbakanlık Cumhuriyet Arşivi, 490.01/ 1455.38.2

-Başbakanlık Cumhuriyet Arşivi, 30.10/26.152.9.

\section{Araștırma Eserler}

- Boratav, Korkut, Türkiye İktisat Tarihi (1908-1985), Gerçek Yayınevi, İstanbul, 1998.

-Çavdar, Tevfik, Türkiye Ekonomisinin Tarihi (1900-1960), İmge Kitabevi, Ankara, 2003.

- Kurtoğlu, Ramazan, Türkiye Ekonomisi (1838-2010), Orıon Kitabevi, Ankara,2015.

-Tezel, Yahya S., Cumhuriyet Döneminin Iktisadi Tarihi, Tarih Vakfi Yurt Yayınları, İstanbul, 2002.

-Toprak Zafer, Milli İktisat-Milli Burjuvazi, Tarih Vakfı Yurt Yayınları, İstanbul, 1995.

-Toprak Zafer, Türkiye'de Ekonomi ve Toplum (1908-1950) Itttihat Terakki ve Devletçilik, Tarih Vakfı Yurt Yayınları, İstanbul,1995.

\footnotetext{
${ }^{53}$ BCA, 030.10/166.154.7, s.45.

${ }^{54}$ BCA, 490.01/1455.38.2, s.8..

${ }^{55}$ BCA, 490.01/1455.38.2, s.9.
} 